\title{
Online Teaching and Practical Implications of Teacher Professional Development
}

\author{
Jayathilakan. P. K a , Dr. Abdul Mohammed Ali Jin nah ${ }^{b}$ \\ ${ }^{a}$ Research Scholar, Jamal Muhammed College, Trichy,(Bharathidasan University, Trichy) \\ ${ }^{\mathrm{b}}$ Associate Professor, Jamal Muhammed College, Trichy,(Bharathidasan University, Trichy)
}

Article History: Received: 10 November 2020; Revised 12 January 2021 Accepted: 27 January 2021; Published online: 5 April 2021

\begin{abstract}
The teaching English website of the British Council identified six different levels of Teacher from "starters" to "experts" suggested that each requires a different kind of professional development. And "professional development" the key to meet today's educational demands. As we know language is a social and cultural activity, Teachers must remain abreast of the exciting and promising development in the teaching strategies.

To live to the challenge of globalization which is in the line with the era of information economy. A quality human capital comes from a quality education process. We live in an age of information explosion; teachers need to continuously update ones knowledge and skills. The field of curriculum in general and second language education in particular have witnessed tremendous changes over the years. A quality human capital comes from a quality education process.

Hargreaves and Fullan (1992, P. IK), "the teacher is the ultimate key to educational change and school improvement". Teachers do not simply implement the curriculam. They define and refine the curriculam they interpret and transform the curricular in a way that makes learning more manageable for the Learners.

The need for Teacher Professional Development is one's evaluation of one's own classroom performance and getting feedback and keep updating, the slow learners and learning disability. To increase knowledge of the teacher (a) referencing (b) research (c) optimum reading (d) awareness (e) elements. 'Regarding Pedagogy (a) Inquiry learning (b) creative and

critical thinking (c) problem solving. Assessment, includes (a) CCA (b) assess of learning (c) assessment for learning (d) Feedback.

A teacher should learn in the day to day environment. Planning lessons and courses managing the lesson and using inclusive practices. Goal oriented mentors/Teachers continuously develop their expertness to implement innovative way of teaching strategies, in case of online teaching. Pedagogical style, class-room processes, and syllabus are fluctuating meritoriously pertaining to the changing need of learning and teaching community. As implementing various dimensions of teaching English effectively. Teaching English online has become more convenient to improve LSRW.

In the digital age valued teachers develop positive learning relationship with their students to establish and maintain an effective learning environment can be created through online method of handling English language teaching. Language teachers especially ,teachers handling English can use their own practice for developing their teaching in the ways of online mode. 3.2million English language teachers in the world, aim to increase capability to improve language teaching with confidence and subject knowledge. ELT Teachers can bring in variety and enthusiasm among the students in language learning process and enhance the students English language skills successfully based online method.

The physical class-room learning process may not be satisfied with the current generations of younger learners. So internet and distance learning which is also known as online method plays a vital role in the world education system and becomes the professional growth of teachers based on their Intellectual, Experimental and Attitudinal aspects.
\end{abstract}

Keywords: On li ne Learning, Interactive, Pedagogy, asynchronous, Intellectual and Professional Development.

\section{Introduction}

Teaching Online benefits, both learners and professional managed teachers. And distance mode of mentoring gives better instructions having much liberal to announce different acquisition process and implement various strategies. There are lot of ESL activities suggested for better on line process. And is now becoming increasingly important all over the world.

Even before the pandemic global e - learning environment

becomes a greater change in International level. And has become very high growth rate. So the growth rate will be much higher by 2026. With the possible disruption to social gathers presented by Coronavirus there is an increased discussion around planning for the use of online teaching and learning. Online method of teaching and learning has developed technique of teaching and learning in highly acceptable way for deserved learners.

Most successful, productive and constructive basement or manifesto marked by sophisticated curriculum method, inspiration, edification, master plan and regale the requirements of all kinds of learners in the society. 
And which leads to professional development of teachers. Because technology influences remote education, virtual learning, mobile learning, etc. Learning through (OER) Open Education Resource or learning teaching technique through web-based learning various methods can be used such as one-on-one video calls. An online teachers must play a vital and pivotal role of guiding students/or learners through one or more online learning experiences, as they are playing an inevitable role in an environment of learning and teaching process. All students acquire much learning opportunities with the help of professionally managed teachers.

Brinkerhoff \& Koroghlanian, reported that the "results indicated that within a four-year time frame, student skills and attitudes remained relatively stable with some positive shifts."

Teacher Professional Development needs analysis clearly show that teacher require training pedagogical platform in real $\mathrm{m}$ of on line integration for young learners improvement in their learning activities. It is also vital for Teacher Professional Development programmes to empower teachers to develop their knowledge and skills activity and variety of learning environments may be depend in the light of online process.

Online teaching and learning will make the curriculum alteration and modifications, according to the present situations of technical knowhow. And during the digital age teacher profession development also assist the revolutionary changes pertaining to the style of curriculum. Professionally managed teachers can refined and improve their critical thinking, problem solving, Assessment- includes,( a) CCA (b) Assess of learning(c)assessment for learning and (d) feedback.

\section{Meaning \& Concept Of Online - Learning}

It is true that online teaching make education or learning more accessible, to all kinds of learners. And we know online learning is just one type of distance learning. But some times online learning is not free from lack of quality in teaching and learning process. It is reducing the opportunities of face to face interactions. Online process of teaching and learning encourage the mentor and the learner to make their own learning platform.

The learning option has widely changed into internet without direct physical presence. Wherever and whenever we need we will get it on the spot, due to its flexibility. The scope of selection for online mode is very much essential and most acceptable and useful. Best mobile Apps like Fox Fi (Free Limited Mode), Audioboo are useful for Professional Managed Teachers. And they can do a lot of heavy lifting through Online supporting to their students based on distance mode.

\section{Types of E - Learning}

There are 10 types of e - learni ng such as;

1) Computer Managed Learning (CML) 2) Computer Assisted Instruction

3) Synchronous on Learni ng 4) Asynchronous 0 nline Learni ng 5) Fixed E - Learni ng

6) Adaptive - E - Learning 7) Linear E - Learning 8) Interactive 0 nline Learning

9) Individual Online Learning and 10) Collaborative 0 nline Learning.

And these are the technical elements which hel p the practical implications of Teacher Professional Development, in the aspects of imparting online classes. Good online teaching provide plenty of materials that allow students to make choices that motivate their interests and what they have access to at home.

The effectiveness of online courses in distance education was measured based on three elements namely; 1) Social Presence 2) Cognitive Presence and 3) Teaching Presence. Based on the theory of critical thinking, the inquiry triggers students to explore, understand and investigate. 


\section{GRAPHICAL REPRESENTATION OF TRAINI PROVIDED TO TEACHERS FOR REMOTE TEACHING, BY REGION}

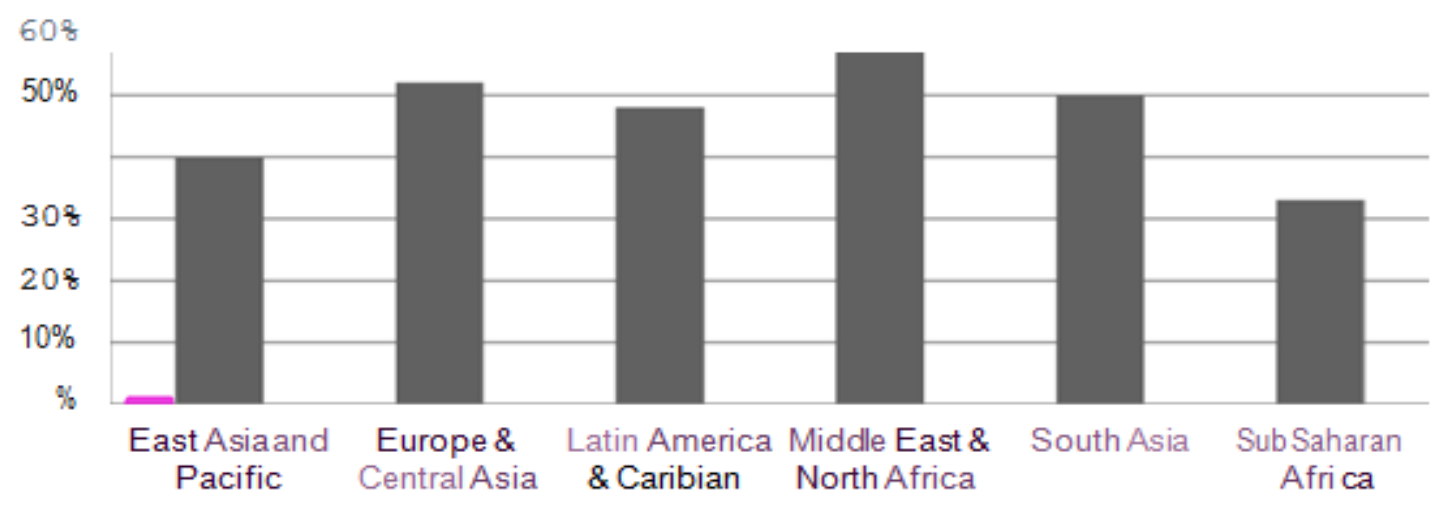

Between 20 and $30 \%$ of countries in East Asia and Pacific, Europe and Central Asia, and South Asia are integrate counseling with mentors. This means teachers professional development has become priority for nations across the globe. In South Asia, 50\% of countries come up with certain direction to teachers on how to involve with learners, during pandemic global situations. And close to $60 \%$ use online mode and to $35 \%$ give out educational videos online as per shown in the graph.

\section{Practical Participation In Online Learning}

Online learning is a growing and exciting new way to learn about almost anything. However, learning online is different from learning in a face - to- face setting. As stated by UNESCO, being the flare-up of Covid-19 go about some 1.37 billion learners in 138 countries world wide have been forced by school and University.

As a practical part, ESL Teaching online should enhance wide variety of interesting, enjoying activities; such as role plays, dictation practice, making predictions activities, breaking news, brainstorming activities, live-demo, onIine teaching games, develop phonetics, mock interview and say words of picture they see and daily routine activity.

\section{SOME DO'S \& DONT'S}

Let us have a glance on some do's and dont's as a practical participations; 1) Do introduce yourself. 2) Read the course expectations.3) Do respect the class-mates.4) Do increase digital information literacy.5) Do create a supportive learning enviroment.6) Use a mix of learning tools for better engagement. 7) provide on going feedback.8)Do record your lecture and show your face. 9) Do keep videos short 10) Do use existing resources. 11) provide interactive activities. 12) Invite learners contributions. 13) Don't be a wall flower 14)Don't blame assigments on technical problems. 15)Don't ignore the additional online.

So online instructor can help to create a successful learning experience by implementing stable teacher professional development. Giving a global perspective, fostering innovations through online teaching and learning in pedagogical practices through Teacher Professional Development can be possible. Because online method of teaching and learning can be planned to array a variety of acquisition process and styles, among young learners, as it has numerous advantages, over traditional learning methods. The emergence of worldwide web in 1991 became a sturdy spur for operating online education, as per survey report. According to the Survey Report of Kerala(India) Sasthra Sahithya Parishth only $67 \%$ of Kerala students directly watching online classes.

\section{Conclusion}

The success of online course in distance education was unfiltered, formulated on three elements namely, social presence, cognitive presence and teaching presence. Hypothesis of critical thinking inquisitive set off learners to survey, recognize and inspect.

It is true that online education presents more opportunities in situations where traditional education has difficult running. Finally, the success of the online education depends basically on the environment surroundings, many nation has succeed to follow this system as they apply it is appropriate- online education has been proven to be resultant way for students to acquire knowledge. The performance of teachers and learning capacity of students is easily trackable in online classes. It is sorry to say that many students don't get opportunity due to lack of money, lack of online access. 
Online education has brought a positive impact among the learners and teachers. In the Era of digitalization the scope of online education develop even more and will be beneficial for all sorts of learners.

Online process encircled and enrich a wide range of technologies such as the worldwide, web, email, chat, new groups and text, audio and video conferencing delivered over computer networks to impart education. It helps the learners to learn at their own pace, pertaining to their own convenience and these circumstances also motivate and enrich professional development of teachers.

\section{References}

Teaching and Learning online Communication,Community and Assessment.

A Hand book for U Mass Faculty.

Teacher Edn and Professional Development - By Christie Martin and Drew Policy.

Teacher - Centred Professional Development. Gabriel Diaz - Maggioli.

Teachers' Professional Develop ment. Assessment, Training and Learning. Sabi re Krolack — Schwwerdt, Sabi n Glock and Matthias Bohmer(Eds) 